\title{
PEMBUATAN MEDIA PEMBELAJARAN TRAINER INSTALASI LISTRIK PENERANGAN PADA MATA PELAJARAN INSTALASI LISTRIK UNTUK MENINGKATKAN HASIL BELAJAR SISWA KELAS XI SMK PGRI 1 MEJAYAN TAHUN PELAJARAN 2015/2016
}

\author{
Yudhistira Sukmawardana ${ }^{1}$, Prabakti Endramawan ${ }^{2}$, Agus Hariwibowo ${ }^{3}$ \\ ${ }^{1}$ Prodi Pendidikan Teknik Elektro, FPTK, IKIP PGRI Madiun \\ Madiun, 63118, Indonesia \\ ${ }^{2}$ Prodi Pendidikan Teknik Elektro, FPTK, IKIP PGRI Madiun \\ Madiun, 63118, Indonesia \\ Email: yudhistirapte@gmail.com
}

\begin{abstract}
ABSTRAK
Penelitian ini bertujuan untuk mengetahui peningkatan hasil belajar teknik instalasi tenaga listrik dengan menggunakan media pembelajaran trainer instalasi listrik penerangan pada siswa kelas XI L teknik instalasi tenaga listrik SMK PGRI 1 Mejayan. Populasi penelitian ini adalah siswa kelas XI L Teknik instalasi tenaga listrik berjumlah 30 orang. Pelaksanaan penelitian dilakukan dalam 8 kali tatap muka pada dua siklus, siklus pertama dan siklus kedua yang terdiri atas tahap perencanaan, tahap pelaksanaan, tahap pengamatan dan tahap refleksi. Hasil penelitian menunjukan bahwa hasil belajar siswa mengalami peningkatan setelah dilakukan pembelajaran dengan menggunakan trainer instalasi listrik penerangan. Dari tes awal secara klasikal pada siklus pertama 83,33\% meningkat menjadi $100 \%$ pada akhir siklus kedua.
\end{abstract}

Kata Kunci: Media Pembelajaran, Hasil Belajar

\section{Pendahuluan}

Sekolah menengah kejuruan (SMK) merupakan pendidikan yang mempersiapkan siswa untuk dapat bekerja dalam bidang tertentu. Berbagai

usaha sekolah dalam mempersiapkan siswa agar bisa bekerja sesuai dengan bidang keahlian yang dimiliki diantaranya, memberikan bekal kompetensi yang sesuai dengan bidang kejuruan masing-masing.

Teknik pemanfaatan tenaga listrik merupakan salah satu jurusan dari Sekolah Menengah Kejuruan (SMK) yang dipersiapkan untuk dapat bekerja dan berwirausaha dalam perbaikan kerusakan peralatan industri dan peralatan rumah tangga. Kompetensi yang diperoleh siswa harus sesuai dengan kriteria atau benarbenar menjadi tenaga ahli yang siap bekerja pada sebuah industri, maka keahlian yang diberikan disalurkan lewat proses pembelajaran. Dalam proses pembelajaran kegiatan yang dilakuan adalah kegiatan belajar mengajar.

Proses pembelajaran merupakan bagian penting dan berpengaruh dalam upaya membentuk dan meningkatkan kompetensi siswa. Dalam proses pembelajaran siswa menyerap ilmu serta menyalurkan ilmunya kepada orang lain. Ada empat komponen yang harus dipenuhi dalam proses pembelajaran. Komponenkomponen tersebut adalah tujuan, bahan, metode dan media serta penilaian. Keempat komponen tersebut saling berhubungan dan saling mempengaruhi satu sama lain.

Alat atau media pembelajaran yang digunakan dalam proses pembelajaran berfungsi sebagai jembatan atau media transformasi pelajaran terhadap tujuan yang ingin dicapai. Alat pembelajaran sebagai salah satu sumber belajar yang dapat menyalurkan pesan, dapat membantu guru dalam mengatasi 
gangguan-ganguan yang terjadi dalam proses pembelajaran (Sadiman, 2011). Oleh karena itu media pembelajaran yang digunakan pada suatu proses pengajaran sangat berpengaruh sekali terhadap daya serap para peserta didik terhadap materi pelajaran yang diajarkan. Disini guru dituntut untuk kreatif dalam memilih media pembelajaran yang efektif yang mampu diserap oleh anak didiknya.

Salah satu bentuk dari media pembelajaran adalah alat pembelajaran atau juga disebut trainer. Alat Pembelajaran merupakan bagian dari jenis media pembelajaran yang dapat menyalurkan pesan yang akan disampaikan kepada siswa (Gerlach 1980:5). Pada saat ini kebanyakan trainer yang digunakan sebagai media belajar oleh guru masih kurang variatif. Masih banyak alat praktek yang belum diujicobakan oleh siswa. Dengan kurang variatifnya trainer tersebut maka ilmu yang didapat oleh siswa kurang maksimal. Ini dikhawatirkan saat siswa terjun di dunia industri menjadi tidak siap.

Kasus yang terjadi yaitu di SMK PGRI 1 Mejayan. Trainer yang digunakan sebagai media pembelajaran kurang bervariasi dan guru tidak menggunakan lembar kerja praktek siswa atau job sheet pada saat melakukan proses pembelajaran.

Salah satu mata pelajaran yang digunakan dalam penelitian adalah kompetensi memasang dan menyambung sistm pengawatan. Pada kompetensi ini untuk menunjang kualitas belajar yang optimal perlu adanya dukungan dari beberapa media belajar yang baik. Kurangnya pengetahuan dibidang praktek siswa SMK PGRI 1 Mejayan pada kompetensi ini adalah salah satunya karena media belajar yang berupa alat praktek dan lembar kerja praktek siswa yang masih kurang bervariasi. Alat praktek tersebut yaitu pada trainer instalasi penerangan. Pada kompetensi ini membutuhkan suatu trainer instalasi penerangan yang memiliki variasi lebih banyak komponen dan penggunaannya.

Bertolak dari uraian diatas maka perlu adanya trainer instalasi penerangan yang lebih baik yaitu pengadaan trainer instalasi listrik pada rumah tinggal yang dilengkapi dengan saklar tukar sebagai pendukung proses belajar mengajar.

Berdasarkan latar belakang, maka rumusan masalah dalam penelitian ini adalah untuk mengetahui peningkatan hasil belajar siswa menggunakan trainer instalasi penerangan di SMK PGRI 1 Mejayan tahun 2015/2016.

\section{Metode}

Penelitian ini merupakan penelitian tindakan kelas (Classroom Action Research) dengan langkah penelitian meliputi perencanaan, pelaksanaan tindakan, pengamatan/observasi, dan refleksi.

Subjek dalam penelitian ini adalah siswa dalam hal ini merupakan siswa kelas XI Jurusan TITL (Teknik Instalasi Tenaga Listrik) SMK PGRI 1 Mejayan Kabupaten Madiun Jawa Timur yang diteliti minat belajarnya melalui penggunaan trainer instalasi listrik penerangan.

Teknik pengumpulan data pada penelitian ini menggunakan tes dan observasi. Sedangkan analisis data yang dilakukan juga berupa analisis kuantitatif.

Data masukan pada penelitian ini adalah data kuantitatif. Sehingga analisis data yang dilakukan juga berupa analisis kuantitatif. Data kuantitatif diperoleh dari observasi tentang kinerja siswa yang berkaitan dengan interaksi kelas. Analisis kuantitatif ini digunakan untuk melihat seberapa besar interaksi kelas yang terjadi pada masing-masing siklus. Data kuantitatif yang lain diperoleh melalui penilaian praktek dan analisis kuantitatif ini digunakan untuk mengetahui pemahaman konsep siswa sebelum dan sesudah melaksanakan kegiatan. Pada validitas job sheet dilakukan dengan cara validitas isi/content validity dengan cara membandingkan isi instrument dengan materi pelajaran yang telah diajarkan.

\section{Hasil Penelitian}

Data nilai awal diperoleh dari praktikum langsung oleh siswa tanpa melalui siklus. Perolehan data awal yang didapat adalah sebagai berikut: pada daftar nilai awal diperoleh nilai rata-rata siswa sebesar 68,83 dengan jumlah siswa yang tuntas sebanyak 15 anak (50,00\%), siswa 
yang tidak tuntas sebanyak 15 anak $(50,00 \%)$. Ditinjau dari distribusi frekuensi dapat dilihat pada Gambar 1 berikut.

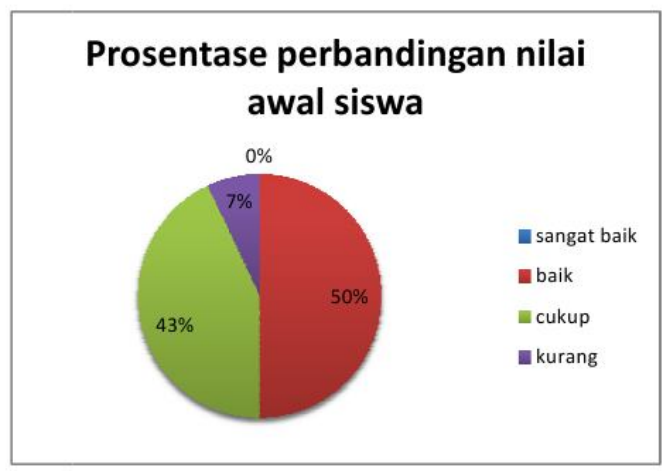

Gambar 1. Prosentasi Nilai Awal Siswa

Berdasarkan Gambar 1, dapat dapat kita ketahui bahwa siswa yang baik sebanyak $15(50 \%)$, siswa yang cukup sebanyak $13(43,33 \%)$ dan, siswa yang kurang sebanyak 2 (6,67\%), untuk memperjelas perbandingan nilai siswa, kita buat diagram lingkaran.

Mengacu pada proses pembelajaran awal yang kurang memuaskan, maka guru menerapkan pembelajaran pada materi memasang dan menyambung sistem pengawatan menggunakan trainer pengawatan instalasi penerangan listrik. Pelaksanaan penelitian terdiri dari 2 siklus.

\section{Siklus I}

Pada tahap ini penelitian dilakukan denagn tahap perencanaan (planning), pelaksanaan (acting), pengamatan (observing), refleksi (reflecting).

Tahap perencanaan (planning) meliputi perancangan Rencana Pelaksanaan Pembelajaran menggunakan implementasi pembelajaran menggunakan trainer (RPP) instalasi penerangan listrik dengan materi memasang dan menyambung system pengawatan dengan saklar tunggal dan saklar seri, perancangan Lembar Kerja Siswa (LKS), perancangan lembar observasi, angket, dan persiapan sarana prasarana trainer instalasi.

Tahap pelaksanaan (acting) dilaksanakan dalam dua pertemuan. Pertemuan pertama berisi penyampaian penjelasan materi pengawatan instalasi dengan saklar tunggal, kemudian dilanjutkan dengan pemberian job sheet untuk memperjelas dan lembar kerja praktek pada masing- masing siswa, kemudian dilakukan kegiatan praktek dan penilaian praktek, setelah itu menyimpulkan penjelasan materi secara bersama- sama. Pertemuan kedua berisi penyampaian penjelasan materi pengawatan instalasi dengan saklar seri kemudian dilanjutkan dengan pemberian job sheet untuk memperjelas dan lembar kerja praktek pada masing-masing siswa, kemudian dilakukan kegiatan praktek dan penilaian praktek, setelah itu menyimpulkan penjelasan materi secara bersama-sama.

Tahap pengamatan (observing) difokuskan pada observasi pelaksanaan pembelajaran, kinerja siswa, dan kinerja guru selama berlangsung pembelajaran.

Tahap refleksi (reflecting) merupakan analisis dari hasil observasi dan hasil tes. Refleksi pada siklus I dilaksanakan segera setelah tahap pelaksanaan/tindakan selesai. Refleksi siklus I meliputi hasil observasi dan hasil tes evaluasi praktek siklus I.

Hasil analisis data tes siklus I dengan sub materi Pengawatan instalasi menggunakan saklar tunggal dan saklar seri., diperoleh nilai rata-rata siswa sebesar 76,00 yang tuntas sebanyak 25 anak $(83,33 \%)$, siswa yang tidak tuntas sebanyak 5 anak $(16,66 \%)$ dengan nilai tertinggi 90 nilai terendah 55,00. Prosentasi hasil belajar siswa dapat dilihat pada Gambar 2.

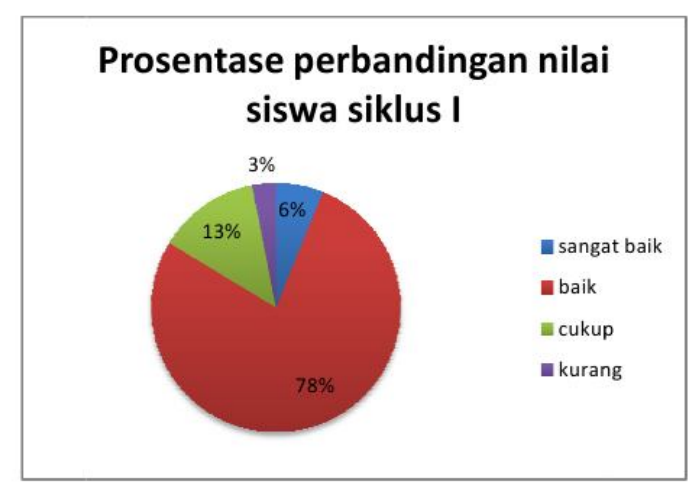

Gambar 2. Prosentase Perbandingan

Nilai Siswa Siklus I

Berdasarkan Gambar 2, dapat dapat kita ketahui bahwa siswa yang sangat baik sebanyak $2(6,67 \%)$, siswa yang sebanyak 
23 (76,67\%), siswa yang cukup sebanyak $4(13,33 \%)$ dan, siswa yang kurang sebanyak $1(3,33 \%)$.

Pada siklus I pertemuan I diperoleh jumlah skor kinerja siswa dalam pembelajaran adalah 15 dengan persentase $60 \%$, dengan kriteria kinerja siswa dalam pembelajaran cukup baik. Sedangkan untuk pertemuan II diperoleh jumlah skor kinerja siswa dalam pembelajaran adalah 16 dengan persentase $64 \%$, dengan kriteria kinerja siswa dalam pembelajaran baik.

Hasil observasi pada siklus I diperoleh data bahwa: (1) siswa masih susah untuk berinteraksi dengan guru, ini terlihat dari diskusi yang dilakukan oleh guru kurang bisa berjalan, (2) siswa kurang melakukan persiapan awal sebelum melakukan praktek, (3) siswa masih suka kurang memperhatikan penjelasan dari guru, (4) siswa masih belum berani bertanya, (5) siswa masih terkesan malu untuk bertanya.

Berdasarkan angket refleksi terhadap pembelajaran, pembelajaran memasang dan menyambung sistem pengawatan menggunakan trainer pengawatan instalasi penerangan listrik menyenangkan. Siswa merasa senang praktek menggunakan trainer. Penggunaan media belajar berupa trainer instalasi penerangan dinilai lebih mudah dalam pemahamanya. Adanya job sheet juga sangat membantu dalam pemahaman serta menambah ketertarikan dan mendorong siswa untuk terus belajar mata pelajaran instalasi dasar penerangan listrik. Namun ada sebagian siswa yang merasa pembelajaran dengan trainer pengawatan instalasi penerangan listrik membuat siswa bingung.

Namun demikian, penggunaan media belajar berupa trainer instalasi penerangan dinilai lebih mudah dalam pemahamanya. Adanya job sheet juga sangat membantu dalam pemahaman serta menambah ketertarikan dan mendorong siswa untuk terus belajar mata pelajaran instalasi dasar penerangan listrik. Demonstrasi alat pembelajaran yang dilakukan oleh guru dimaksudkan untuk memperkuat isi materi yang disampaikan sekaligus dapat memperlihatkan proses terjadinya sesuatu (Nana Sudjana, 2008:78). Setelah seorang guru melaksanakan demonstrasi alat pembelajaran, kegiatan berikutnya adalah memberi kesempatan praktek kepada peserta didik.

Jika ditinjau dari kinerja guru, masih canggung dalam penggunaan trainer pengawatan instalasi penerangan listrik. Saat menjelaskan cara pemasangan pengawatan instalasi listrik guru masih bingung. Hal ini dikarenakan pembelajaran menggunakan media berupa trainer instalasi penerangan listrik baru pertama kali digunakan oleh guru. Dalam menindaklanjuti permasalahan ini guru harus lebih siap dalam menggunakan media dengan cara mempelajari terlebih dahulu pemakaian trainer instalasi penerangan rumah tersebut sebelum terjun ke kelas.

Masih adanya sebagian siswa yang merasa kesulitan belajar menggunakan trainer pengawatan instalasi penerangan listrik dan juga mengacu refleksi hasil observasi, maka dilanjutkan pada siklus II.

Beberapa hal yang harus diperbaiki pada siklus I dan diharapkan dapat dilaksanakan pada siklus II antara lain:

a. Pengelolaan waktu selama proses pembelajaran. Waktu yang digunakan untuk menerangkan materi terlalu lama, hal ini menyebabkan waktu yang digunakan untuk praktek kurang. Untuk itu guru harus lebih memperhatikan waktu agar materi dan praktek yang diberikan bisa dapat terselesaikan dengan tepat waktu.

b. Interaksi antara guru dan siswa saat pembelajaran masih kurang. Pada saat pembelajaran hanya sebagian kecil siswa yang bertanya serta dapat menjawab pertanyaan guru dan dapat menanggapi apa yang guru jelaskan. Hal ini dikarenakan siswa masih malu untuk bertanya ataupun memberikan pernyataan kepada guru atau teman. Untuk tindak lanjut berikutnya yang dilakukan guru agar siswa bias lebih aktif berinteraksi adalah guru harus lebih aktif melakukan interaksi kepada siswa agar siswa terpancing, sehingga suasana kelas menjadi lebih hidup.

c. Kemampuan guru dalam menguasai penggunaan trainer instalasi 
penerangan rumah. Saat melakukan kegiatan praktek guru masih canggung menggunakan trainer instalasi penerangan rumah,ini terjadi karena guru baru pertama kali mengajar menggunakan trainer tersebut. Untuk menindak lanjuti permasalahan ini guru harus lebih siap dalam menggunakan media dengan cara mempelajari terlebih dahulu pemakaian trainer instalasi penerangan rumah tersebut sebelum terjun ke kelas.

d. Siswa yang masih kurang dalam melakukan persiapan awal sebelum melakukan praktek serta masih kurang juga dalam merapikan kembali alat-alat praktek. Ini dikarenakan siswa ingin cepat-cepat menyelesaikan kegiatan praktek. Yang harus dilakukan untuk menindaklanjutinya yaitu guru memberikan pengarahan kepada siswa agar jangan tergesa-gesa melakukan kegiatan praktek.

\section{Siklus II}

Pada tahap siklus II tahap penelitian sama dengan siklus I yaitu tahap perencanaan (planning), pelaksanaan (acting), pengamatan (observing), refleksi (reflecting).

Tahap perencanaan (planning) dilakukan dengan meningkatkan pengorganisasian waktu dalam pembelajaran dengan baik sehingga semua tahap dalam pembelajaran dapat dilaksanakan dengan baik dan optimal. Dilanjutkan dengan perancangan RPP, LKS, lembar observasi, angket, dan persiapan sarana prasarana yang disesuaikan dengan materi yang akan disampaikan.

Tahap pelaksanaan (acting) pada siklus II dilaksanakan dua pertemuan. Pertemuan pertama berisi penyampaian materi menyambung system pengawatan dengan saklar tukar hubungan gudang kemudian dilanjutkan dengan pemberian job sheet sebagai Lembar kerja praktek siswa, dilakukan pembahasan dan penarikan kesimpulan secara bersama-sama. Pertemuan kedua berisi penyampaian materi menyambung system pengawatan dengan saklar tukar hubungan lorong atau rumah bertingkat, kemudian dilanjutkan dengan pemberian job sheet sebagai Lembar kerja praktek siswa, dilakukan pembahasan dan penarikan kesimpulan secara bersama-sama.

Tahap pengamatan (observing) dan refleksi (reflecting) pada siklus II dilakukan seperti halnya pada siklus I.

Hasil penelitian pada siklus II menunjukkan bahwa pada sub materi memasang sistem pengawatan dengan saklar tukar hubungan gudang dan lorong, diperoleh nilai rata-rata siswa sebesar 87,50 siswa yang tuntas sebanyak 30 anak $(96,67 \%)$, siswa yang tidak tuntas sebanyak 0 anak $(0,00 \%)$ dengan nilai tertinggi 100 dan nilai terendah 75 . Prosentase nilai siswa pada siklus II dapat dilihat pada Gambar 3 .

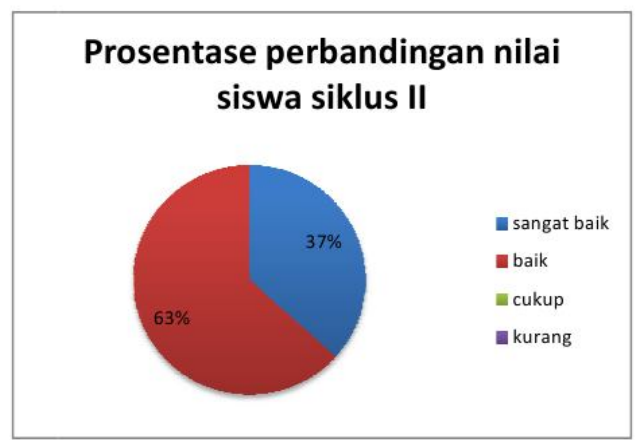

Gambar 3. Prosentase perbandingan nilai siswa siklus II

Berdasarkan tabel diatas dapat dapat diketahui bahwa siswa yang sangat baik sebanyak $11(36,66 \%)$, siswa yang baik dan sebanyak $19(63,33 \%)$.

Pada siklus II pertemuan I diperoleh jumlah skor kinerja siswa dalam pembelajaran adalah 18 dengan persentase $72 \%$, dengan kriteria kinerja siswa dalam pembelajaran baik. Sedangkan untuk pertemuan II diperoleh jumlah skor kinerja siswa dalam pembelajaran adalah 20 dengan persentase $80 \%$, dengan criteria kinerja siswa dalam pembelajaran baik.

Hasil observasi pada siklus II menunjukkan bahwa: (1) siswa telah terbiasa dengan pembelajaran praktek menggunakan trainer instalasi penerangan rumah yang dilaksanakan sehingga kegiatan pembelajaran berlangsung dengan baik, (2) keantusiasan siswa dalam mengerjakan praktek baik, (3) siswa sudah 
cukup aktif dalam bertanya, mengemukakan pendapat dan mempresentasikan hasil diskusinya, (4) hubungan kerjasama antar siswa sudah baik sehingga suasana diskusi antar siswa sudah efektif.

Jika ditinjau dari kinerja guru, pembelajaran menggunakan trainer instalasi penerangan rumah yang dilakukan guru pada siklus II sudah berlangsung efektif. Guru sudah berhasil mengorganisaikan waktu dengan baik. Dalam pembelajaran guru telah mampu menguasai penggunaan trainer instalasi penerangan rumah serta guru sudah dapat memotivasi siswa untuk aktif dalam pembelajaran seperti siswa berani bertanya, memberi tanggapan atas penjelasan guru, siswa dapat menjawab pertanyaan guru dengan benar.

Berdasarkan angket refleksi terhadap pembelajaran di atas, pembelajaran memasang dan menyambung sistem pengawatan menggunakan trainer pengawatan instalasi penerangan listrik sangat menyenangkan dan mudah diikuti. Penyajian hasil karya yang dilaksanakan menyenangkan bagi siswa. Ada sejumlah peningkatan respon positif dibandingkan dengan siklus I.

Hasil angket terhadap sikap siswa menunjukkan bahwa pelajaran instalasi listrik merupakan pelajaran yang digemari siswa. Dari hasil penelitian menunjukkan $57 \%$ menggemari pelajaran instalasi listrik, $40 \%$ sangat menggemari pelajaran instalasi listrik dan hanya 3\% yang tidak menggemari pelajaran tersebut.

Minat yang tinggi terhadap praktek, selain dilihat dari sikapnya, dapat dilihat juga dari keinginan dapat memperagakan penggunaan trainer, kedisiplinan dan selalu ingin maju. Hasil survei menunjukan bahwa sebagian besar siswa memperagakan penggunaan trainer dengan sungguh-sungguh, mempersiapkan perlengkapan terlebih dahulu, dan memahami penggunaan sampai bisa.

Ketekunan merupakan indikator tinggi rendahnya minat siswa terhadap pelajaran instalasi listrik. Ketekunan ini dapat dilihat dari usaha dan rajin tidaknya berlatih. Hasil survei menunjukkan bahwa sebagian besar siswa jika mengalami kesulitan dalam praktek tidak akan putus asa dalam berlatih.

Minat yang tinggi dapat dipengaruhi oleh motivasi atau dorongan dari dalam diri sendiri. Namun dorongan dari lingkungan merupakan motivasi yang dapat menambah minatnya menjadi lebih tinggi. Hasil survey menunjukkan bahwa minat yang tinggi dari siswa terhadap pelajaran instalasi listrik karena dorongan dan dukungan dari teman-temannya.

Secara keseluruhan, pada siklus II ini kinerja siswa sudah baik dan meningkat dibandingkan siklus I. Hal ini terlihat dari meningkatnya hasil belajar siswa saat pembelajaran. Hasil survei menjelaskan juga bahwa sebagian besar siswa mempunyai inisiatif yang tinggi untuk melakukan praktek sendiri, apabila guru praktek tidak datang. Hal ini menunjukan minat yang tinggi terhadap praktek dengan trainer. Hasil peningkatan pembelajaran tiap siklus dapat dilihat pada Gambar 4.

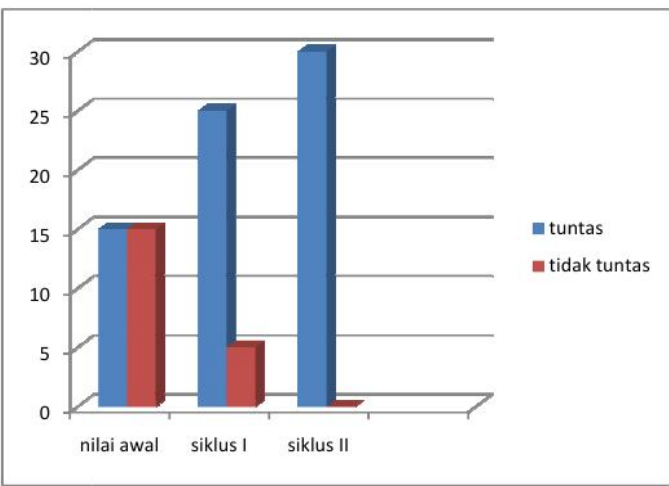

Gambar 4. Perbandingan Nilai Awal Siswa, Siklus I, dan Siklus II.

Mengacu pada Gambar 1, menunjukan bahwa indikator keberasilan telah tercapai. Ada peningkatan minat belajar siswa dalam kegiatan belajar mengajar melalui pembelajaran mata pelajaran instalasi dasar penerangan listrik menggunakan trainer instalasi penerangan rumah pada siswa kelas XI TITL SMK PGRI Mejayan.

\section{Kesimpulan}

Hasil belajar siswa kelas XI terhadap pelajaran instalasi listrik yang dilakukan di Sekolah dalam kategori tinggi. Diamati dari hasil belajar praktek siswa pada siklus I menunjukan nilai tertinggi 90 dan 
nilai terendah 52,5. Dilihat dari ketuntasan belajar secara klasikal mencapai 83,33\%.

Sehingga penelitian tindakan kelas pada siklus I sudah dikatakan berhasil tetapi masih perlu pembenahan. Padasikus II hasil belajar praktek siswa menunjukan nilai tertinggi 100 dan nilai terendah 75. Dilihat dari ketuntasan belajar secara klasikal mencapai $100 \%$ selain itu melalui pembelajaran dengan trainer instalasi penerangan pada mata pelajaran instalasi dasar penerangan listrik dapat meningkatkan hasil belajar siswa kelas XI TITL SMK PGRI 1 Mejayan. Tahun Ajaran 2015/2016 pada sub kompetensi memasang dan menyambung system pengawatan. Hasil peningkatan yang diamati adalah Terjadi peningkatan rata-rata hasil belajar praktek dari siklus I kesiklus II adalah sebesar 11,5 dengan ketuntasan klasikal meningkat 12,66\%.

\section{DAFTAR PUSTAKA}

Arif S. Sadiman, dkk. (2011). Media Pendidikan, Pengertian, Pengembangan, dan Pemanfaatannya. Jakarta: PT. Raja Grafindo Persada.

Gerlach \& D.P. Ely, 1980, Boston, MA: Allyn and Bacon. Multimedia Learning: Prinsip-prinsip dan Aplikasi, Yogyakarta: Pustaka Pelajar.

Sudjana, Nana. 2008. Dasar-Dasar Proses Belajar mengajar. Bandung: Sinar Baru Algensindo. 